\title{
Some metabolic aspects of vitamin $B_{12}$ deficiency in sheep
}

\author{
By R. M. SMITH and the Late H. R. MARSTON \\ CSIRO Division of Nutritional Biochemistry, \\ Kintore Avenue, Adelaide, South Australia \\ (Received I8 August 1969-Accepted 31 March 1970)
}

\begin{abstract}
1. Studies were made with pair-fed vitamin $B_{12}$-deficient and vitamin $B_{12}$-treated or cobalt-treated ewes fed a Co-deficient diet in cages. Measurements were made of body-weight changes and some observations were made of energy and nitrogen metabolism. The effects of oral Co on energy and nitrogen metabolism were examined in sheep fed the Co-deficient diet, but not yet deficient of vitamin $B_{12}$ in the tissues.

2. The rate of loss of body-weight of vitamin $B_{12}$-deficient sheep was significantly faster $(P<0.0 \mathrm{I})$ than that of pair-fed sheep given $50 \mu \mathrm{g}$ vitamin $\mathrm{B}_{12} / \mathrm{d}$ by injection.

3. In a limited number of observations of pair-fed sheep no significant differences were found in retention of combustible energy from the diet, but excretion of faecal nitrogen was higher in deficient animals than in animals receiving vitamin $\mathrm{B}_{12}$ or Co.

4. There was no significant effect of supplementary Co on energy metabolism, nitrogen metabolism, production of methane or digestibility of fodder in sheep that were not deficient of vitamin $\mathrm{B}_{12}$.
\end{abstract}

Cobalt deficiency in sheep is a wasting disease in which the animal dies in a state of inanition, and, apart from anaemia and fatty liver, without any obvious pathological changes (Marston, 1952; Underwood, 1962). There is a sharp fall in food intake accompanying the fall in body-weight (Marston \& Smith, 1952; Marston, 1970) and the symptoms found are largely those of starvation. Treatment with oral Co or injected vitamin $B_{12}$ is effective either in preventing the appearance of symptoms or in restoring deficient animals to health.

The present experiments with pair-fed animals were undertaken to determine whether the loss in body-weight was due solely to loss of appetite, or whether, in addition, the deficient animal failed to metabolize its fodder efficiently. It was found that the deficient animal lost weight substantially faster than the pair-fed control, and further definition of the metabolic inefficiency implied by this finding was sought in a few studies of energy and nitrogen excretion and of energy expenditure in pair-fed animals.

Although not highly significant, the results indicated that both faecal nitrogen excretion and fasting energy expenditure were greater in deficient animals than in pairfed controls. Within small limits of error there was no effect of supplementary Co per se on the digestibility of the fodder or the metabolism of the animal and the conclusion is reached that the observed symptoms of Co deficiency were entirely due to a lack of vitamin $B_{12}$ in the tissues.

\section{EXPERIMENTAL}

Animals and diet. These were as described by Smith \& Marston (1970), the full ration consisting of $1000 \mathrm{~g}$ wheaten hay-chaff and $50 \mathrm{~g}$ of gluten/d. The hay-chaff fed contained $0.02-0.04 \mu \mathrm{g} \mathrm{Co} / \mathrm{g}$ (dry) and the gluten less than $0.02 \mu \mathrm{g} \mathrm{Co} / \mathrm{g}$ (dry). 
After a training period in cages, and in some instances an initial depletion of vitamin $B_{12}$ reserves on the experimental diet in open-air pens, animals were maintained in collection cages (Marston, 1935) for periods of up to 4 years. If both oral Co (I mg $\mathrm{Co} / \mathrm{d}$ given as a drench at the time of feeding) and vitamin $\mathrm{B}_{12}(5 \circ \mu \mathrm{g}$ cyanocobalamin/ $\mathrm{d}$ injected intramuscularly) were withheld, normal health appeared to be maintained for 20-35 weeks and the full daily ration (1050 g moist weight, or about $940 \mathrm{~g}$ dry weight) was consumed. Thereafter a progressively increasing proportion of the ration was left uneaten, the animals lost weight and, if not treated, died in an emaciated condition in a further $20-35$ weeks.

Pair-fed animals. The time required to produce deficiency symptoms (loss of appetite) varied widely and so pair-fed animals were produced and maintained individually from a pool of fifteen to twenty animals fed the Co-deficient diet. Animals to be pairfed were selected on the basis of similar age, similar food intakes (generally in the range $500-800 \mathrm{~g} / \mathrm{d}$ but in some instances the full food intake of $1050 \mathrm{~g} / \mathrm{d}$ ), and similar body-weights, both animals having generally consumed the deficient diet for a similar time. One animal was then treated continuously with Co or vitamin $B_{12}$ and its food intake restricted to that consumed by its deficient counterpart on the previous day. Food residues were collected and weighed daily and the appropriate mixture of haychaff and gluten was calculated on a moist-weight basis. In periods when nitrogen and combustible energy excretion were measured, food residues were dried at $110^{\circ}$ for $24 \mathrm{~h}$ before weighing and food intakes calculated on a dry-weight basis. In these periods treated animals were pair-fed $2 \mathrm{~d}$ after their deficient counterparts. No food residues were left by treated animals during these periods and only very rarely in the entire series of experiments.

Body-weight changes in pair-fed animals. During the 5-year period reported in Table I, thirty-five pairs of animals were produced in which the treated animals received vitamin $B_{12}$. Observations to be reported were restricted to periods of falling food intake in the range $800 \mathrm{~g} / \mathrm{d}-200 \mathrm{~g} / \mathrm{d}$. Observations were rejected if body-weight differences at the beginning of the period of observation exceeded $3 \mathrm{~kg}$. All observations on eight of the pairs were rejected for this reason. After pair-feeding was established, a stabilization period of 4 weeks was allowed before observations began and, if the animals were shorn, a further 4 weeks stabilization was allowed before observations were resumed. Rates of body-weight loss were calculated from weekly bodyweight values as linear regressions, and in the statistical analysis these were weighted inversely as their variances. The analysis was performed on regressions from twentyseven pairs, and a distinction was made between first observations off pasture and repeat observations on the same pair of animals after temporary recovery of the deficient member on treatment with vitamin $\mathrm{B}_{12}$.

Energy and nitrogen metabolism. During the $14 \mathrm{~d}$ periods in which combustible energy and nitrogen retention were measured, samples of fodder components, food residues and excreta were collected and analysed as described by Marston (1948). Measurements of respiratory exchange were made in the open-circuit calorimeters described by Marston (1948). Heat production is reported either as $\mathrm{kcal} / 24 \mathrm{~h}$ or as $\mathrm{kcal} / \mathrm{W}^{0.73}$ per $24 \mathrm{~h}$. 
Chemical estimations. Co in fodder was estimated by the method of Marston \& Dewey (I940). Blood haemoglobin was measured by the alkaline haematin method standardized by the van Slyke determination of oxygen-carrying capacity and by iron content (Marston \& Lee, I948). Nitrogen was estimated by a Kjeldahl procedure, and combustible energy with an Emerson bomb calorimeter.

\section{RESULTS}

Body-weight changes in pair-fed animals. Two examples of pair-fed vitamin $\mathrm{B}_{12^{-}}$ deficient and vitamin $\mathrm{B}_{12}$-treated animals maintained for long periods on the deficient diet are shown in Fig. $\mathrm{r}$. The deficient member of the pair was periodically treated for 2-4 weeks with $50 \mu \mathrm{g}$ vitamin $B_{12} / \mathrm{d}$ before again being allowed to become deficient. Blood haemoglobin was measured from the time pair-feeding began and shows the typically more pronounced degree of anaemia found in deficient animals than in pairfed animals receiving vitamin $B_{12}$. Although the response in food intake and bodyweight of the deficient animal to vitamin $B_{12}$ was immediate, the haemoglobin response was frequently delayed.

In Fig. I the rate of body-weight loss is perceptibly faster in deficient than in treated animals. Values for rates of body-weight loss were obtained in forty-nine observations on twenty-seven pairs of animals over a 5 -year period. The mean period of observation was 9.6 weeks. Table I summarizes the results for fifteen of these pairs, and shows the individual rates for first observations off pasture. In the final column are shown the ratios between the weighted mean rates for deficient and treated animals respectively for repeat observations like those shown in Fig. I.

Statistical analysis of all the regressions showed that variation between pairs (in first observations) did not differ significantly from variation within pairs (in repeat observations) and that the regressions for deficient and treated animals each comprised a homogeneous population. The values for all forty-nine observations were therefore pooled to give 74 degrees of freedom. The mean rate of body-weight loss for all observations on deficient animals $(0.5464 \mathrm{~kg} /$ week \pm 0.0224 (SEM)) was significantly greater $(P<0.01)$ than that for all observations on treated animals $(0.4365 \mathrm{~kg} /$ week $\pm 0.025 \mathrm{I}(\mathrm{SEM}))$. The corresponding degree of significance for the mean rates shown in Table I for first observations was $P<0.05$, and for the repeat observations indicated in the final column was also $P<0.05$.

The rate of loss of body-weight varied greatly between deficient animals and reflected the rate of loss of appetite, but there was no correlation between these rates and the corresponding ratios. From the mean rates for all observations given above, the deficient animals lost weight $25 \%$ faster than the treated animals.

Nitrogen and energy retention in pair-fed vitamin $B_{12}$-deficient and Co-treated or vitamin $B_{12}$-treated ewes. Three pairs of animals were used when food intakes had fallen to less than $400 \mathrm{~g} / \mathrm{d}$. In two pairs the treated animal received vitamin $B_{12}$ and, in the third pair, Co given by mouth. Two sets of measurements were made with the latter pair.

Results are shown in Tables 2 and 3 . Partly owing to a degree of selective rejection 
of flake-gluten by the deficient animals, food intakes were not perfectly matched and nitrogen intakes of treated animals were about $2 \%$ higher than those for their deficient counterparts while combustible energy intakes were about $4 \%$ lower.

For statistical analysis, values for excretion were expressed as fractions of actual intakes, and on this basis there were no significant differences between deficient and treated animals in any of the quantities measured except faecal nitrogen. Expressed as a fraction of ingested nitrogen, this was significantly higher $(P<0.05)$ in deficient than in treated animals and the effect was consistent for both vitamin $B_{12}$-treated and $\mathrm{Co}$ treated controls.

Energy expenditure of vitamin $B_{12}$-deficient and pair-fed vitamin $B_{12}$-treated animals. Measurements of energy expenditure by respiratory exchange in sheep are not highly accurate unless the animals are thoroughly stabilized on a particular plane of nutrition, but with pair-fed deficient and treated sheep the plane of nutrition was constantly falling. In addition, while the deficient animal was listless and ate its food slowly, the
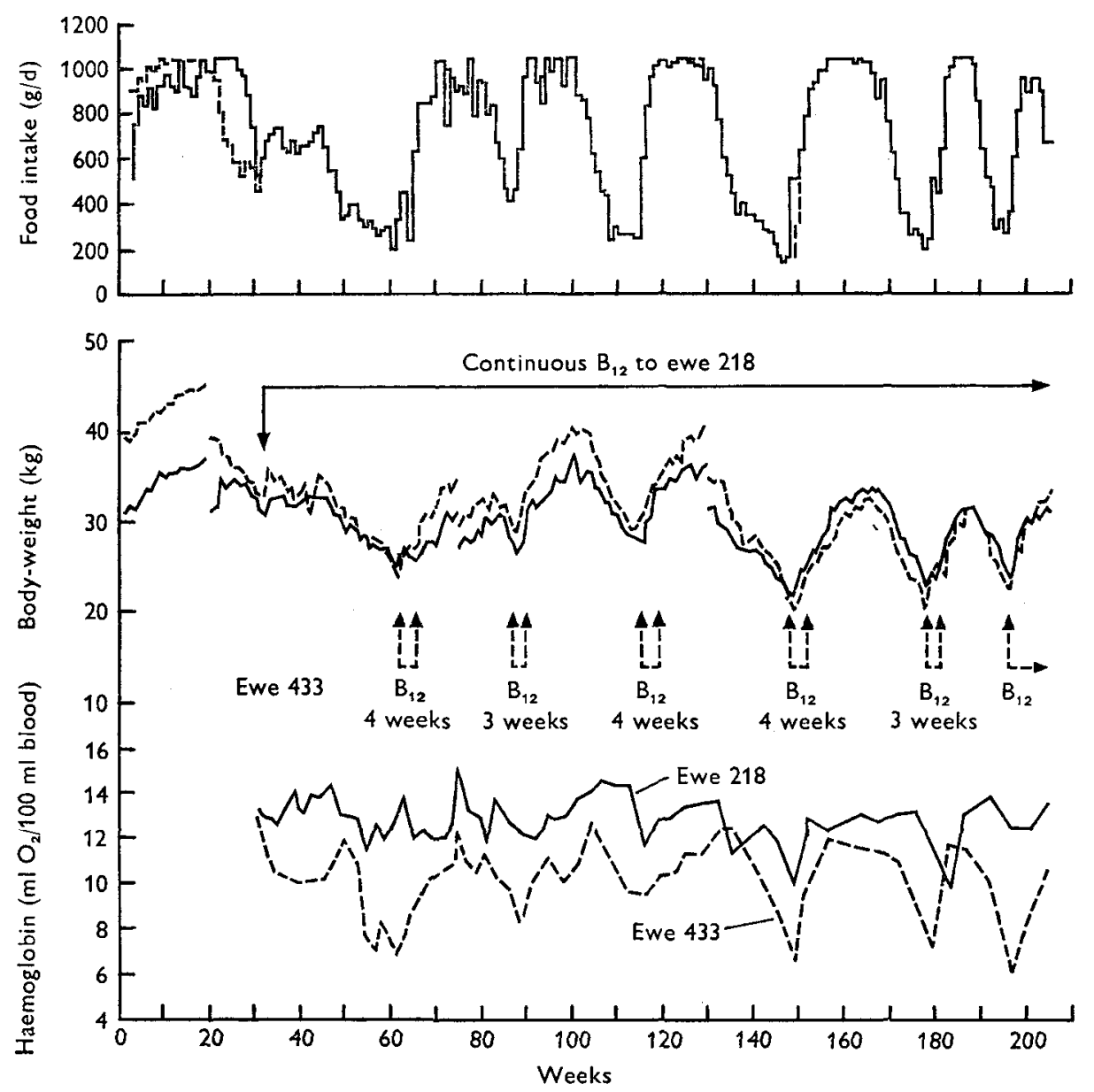

Fig. I A. For legend see opposite page. 

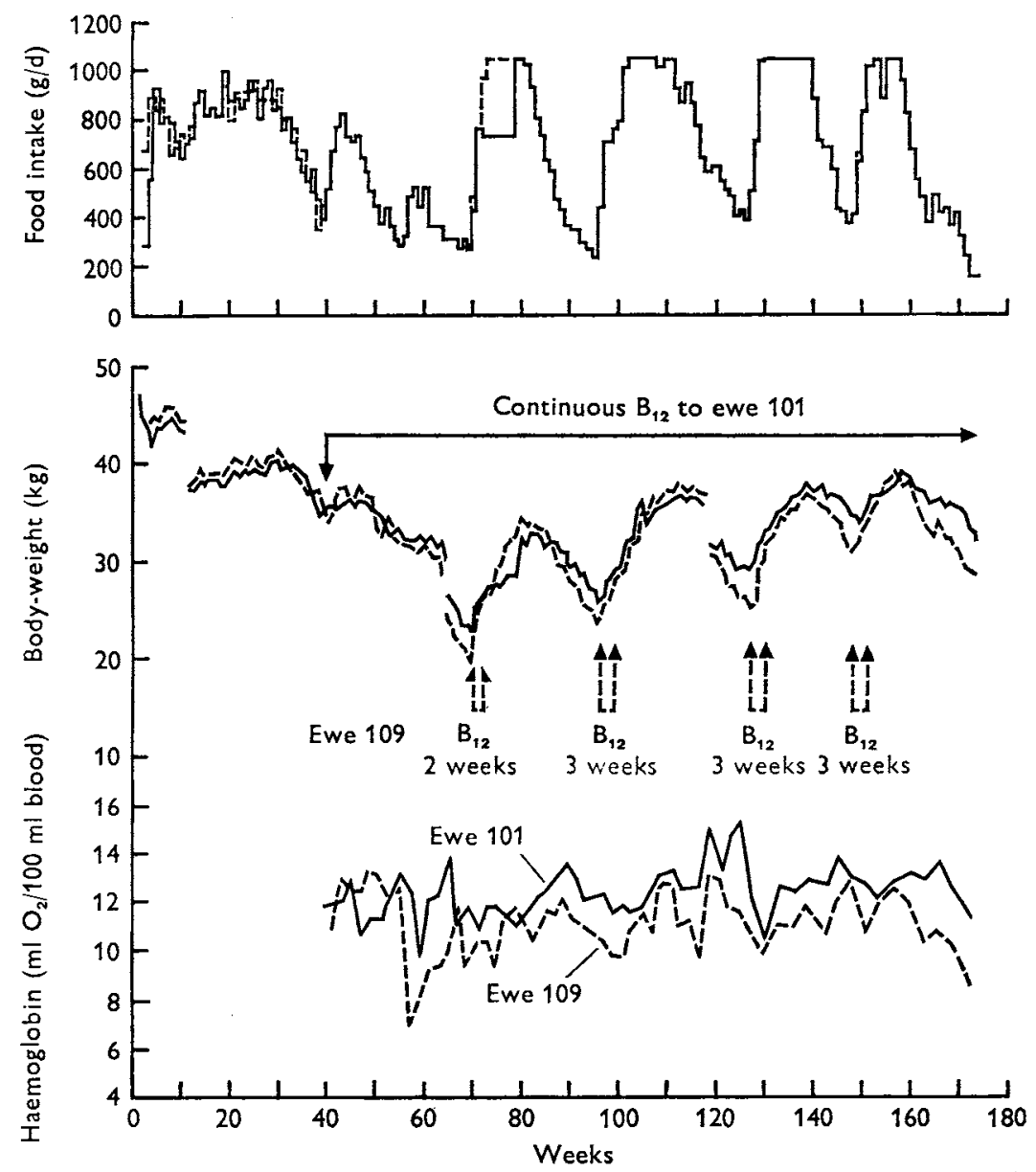

Fig. I B

Fig. 1. Food intake, body-weight and haemoglobin of pair-fed vitamin $B_{12}$-deficient and vitamin $B_{12}$-treated ewes. The deficient animals are represented by broken lines, the pairfed animals injected with $50 \mu \mathrm{g}$ vitamin $\mathrm{B}_{12} / \mathrm{d}$ by solid lines. Breaks in the body-weight curves were caused by shearing. During the periods indicated by arrows, deficient animals were treated for $\mathrm{I}-4$ weeks with $50 \mu \mathrm{g}$ vitamin $\mathrm{B}_{12} / \mathrm{d}$; treatment of the other animal was continuous from the time of pairing as shown by the upper arrow. (A), ewes 433 (deficient) and 218 (treated), 18 months of age at week $\circ$; (B), ewes 109 (deficient) and ror (treated), 30 months of age at week $o$.

pair-fed treated animal consumed its daily ration within a few hours. These factors combine to make measurements of energy expenditure of doubtful value but, nevertheless, a few such measurements were made and are reported below. Urinary nitrogen was not measured and energy expenditure was calculated from total oxygen consumption using simple respiratory quotients.

Table 4 shows the energy expenditure of the pair-fed animals no. 433 and no. 2I 8 (Fig. IA). The measurements were made after 60 weeks on the Co-deficient diet and 27 weeks after pair-feeding began. The animals were 32 months of age; no. 433 weighed $27.2 \mathrm{~kg}$ and no. 218 weighed $26 \cdot 0 \mathrm{~kg}$. Although energy expenditure was 


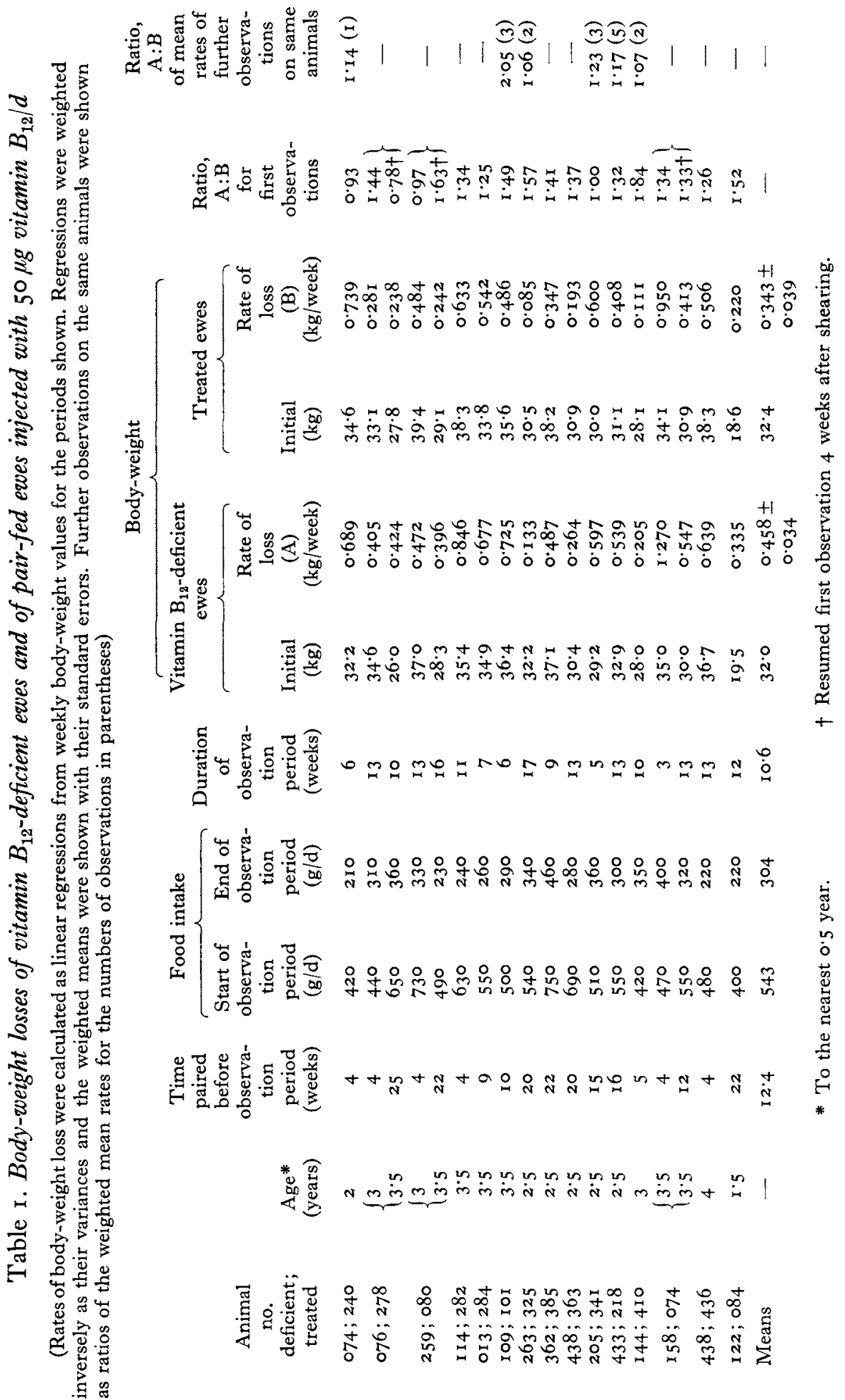


Vol. 24

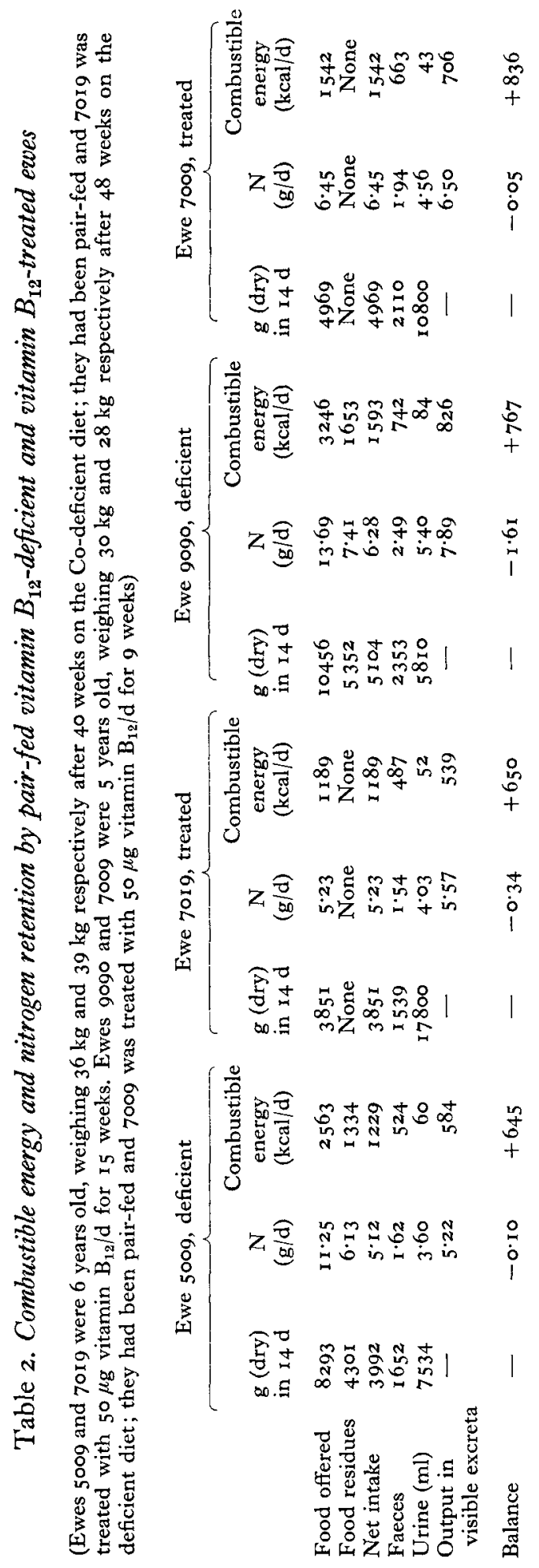


similar in the two animals when fed it appeared to fall more rapidly in the treated animal on fasting.

Two further measurements, each of $24 \mathrm{~h}$ duration, were made on a second pair of animals on the ist day of fast and are given in Table 5. The animals were 3 years of age and had been fed on the Co-deficient diet for 53 weeks when the first measurements were made. Methane was not measured. Energy expenditure on the Ist day of fast was again higher in the deficient animals.

\title{
Table 3. Combustible energy and nitrogen retention by pair-fed vitamin $B_{12}$-deficient and Co-treated ewes
}

\begin{abstract}
(Ewes 9134 and 7049 were given the Co-deficient diet at 3 years of age and pair-fed, and 7049 was treated with I mg Co/d after 36 weeks. Two I4 d collection periods were held at $4 \mathrm{I}$ weeks and 63 weeks. At 41 weeks the body-weight of 9134 was $31 \mathrm{~kg}$ and of $704933 \mathrm{~kg}$, and at 63 weeks body-weights were $23 \mathrm{~kg}$ and $27 \mathrm{~kg}$ respectively. Both animals died at 66 weeks)
\end{abstract}

\begin{tabular}{|c|c|c|c|c|c|c|}
\hline & \multicolumn{6}{|c|}{ Period I } \\
\hline & \multicolumn{3}{|c|}{ Ewe 9134, deficient } & \multicolumn{3}{|c|}{ Ewe 7049, treated } \\
\hline & $\begin{array}{l}\text { g (dry) } \\
\text { in I } 4 \mathrm{~d}\end{array}$ & $\begin{array}{c}N \\
(\mathrm{~g} / \mathrm{d})\end{array}$ & $\begin{array}{c}\text { Combustible } \\
\text { energy } \\
\text { (kcal/d) }\end{array}$ & $\begin{array}{l}g \text { (dry) } \\
\text { in } 14 d\end{array}$ & $\begin{array}{l}\mathbf{N} \\
(\mathrm{g} / \mathrm{d})\end{array}$ & $\begin{array}{c}\text { Combustible } \\
\text { energy } \\
\text { (kcal/d) }\end{array}$ \\
\hline $\begin{array}{l}\text { Food offered } \\
\text { Food residues }\end{array}$ & $\begin{array}{l}9846 \\
6012\end{array}$ & $\begin{array}{r}13 \cdot 50 \\
8 \cdot 10\end{array}$ & $\begin{array}{l}3057 \\
1857\end{array}$ & $\begin{array}{l}3621 \\
\text { None }\end{array}$ & $\begin{array}{l}5 \cdot 44 \\
\text { None }\end{array}$ & $\begin{array}{l}\text { I I } 30 \\
\text { None }\end{array}$ \\
\hline Net intake & 3834 & 5.40 & 1200 & $362 i$ & $5 \cdot 44$ & II 30 \\
\hline Faeces & I 527 & $2 \cdot 17$ & 483 & 1474 & $I \cdot 42$ & 460 \\
\hline Urine (ml) & 7225 & $4 \cdot 62$ & 64 & 4546 & 3.90 & 60 \\
\hline $\begin{array}{l}\text { Output in } \\
\text { visible excreta }\end{array}$ & - & $6 \cdot 79$ & 547 & — & $5 \cdot 32$ & 520 \\
\hline \multirow[t]{4}{*}{ Balance } & - & $-1 \cdot 39$ & +653 & 一 & +0.13 & $+6 I I$ \\
\hline & \multicolumn{6}{|c|}{ Period 2} \\
\hline & \multicolumn{3}{|c|}{ Ewe 9134, deficient } & \multicolumn{3}{|c|}{ Ewe 7049 , treated } \\
\hline & $\begin{array}{l}g \text { (dry) } \\
\text { in I } 4 \mathrm{~d}\end{array}$ & $\underset{(g / d)}{N}$ & $\begin{array}{c}\text { Combustible } \\
\text { energy } \\
\text { (kcal/d) }\end{array}$ & $\begin{array}{l}g(\mathrm{dry}) \\
\text { in } \mathrm{I} 4 \mathrm{~d}\end{array}$ & $\begin{array}{c}N \\
(g / d)\end{array}$ & $\begin{array}{c}\text { Combustible } \\
\text { energy } \\
\text { (kcal/d) }\end{array}$ \\
\hline Food offered & 7052 & $9.5 \mathrm{I}$ & 2168 & $235^{8}$ & $4 \cdot 63$ & 744 \\
\hline Food residues & $45^{28}$ & $4 \cdot 94$ & 1386 & None & None & None \\
\hline Net intake & 2524 & 4.57 & 782 & $235^{8}$ & $4 \cdot 63$ & 744 \\
\hline Faeces & 979 & I'39 & 308 & 952 & $I \cdot 04$ & 293 \\
\hline Urine (ml) & 9650 & $4 \cdot 4 I$ & 48 & 9030 & 3.98 & 34 \\
\hline $\begin{array}{l}\text { Output in } \\
\text { visible excreta }\end{array}$ & - & $5 \cdot 80$ & 356 & - & $5 \cdot 02$ & 327 \\
\hline Balance & - & $-1 \cdot 23$ & +426 & - & -0.39 & +417 \\
\hline
\end{tabular}

The three sets of results constitute only two independent observations and the difference between deficient and treated animals although consistent, is not statistically significant $(0.05<P<0 \cdot 1)$. The findings are, therefore, no more than indicative of a higher fasting energy expenditure in deficient animals on the Ist day of fast.

Digestibility of fodder and energy utilization with and without supplementary Co in animals not deficient of vitamin $B_{12}$. Two animals were used, one receiving $\mathrm{I} \mathrm{mg} \mathrm{Co} / \mathrm{d}$ 
by mouth and both consuming a maintenance ration of the Co-deficient diet. After one set of measurements was completed Co treatment was reversed, the animals were again stabilized and the measurements repeated. The maximum periods on the deficient diet without Co ( 8 weeks for no. 077 and 6 weeks for no. I13) were not long enough seriously to deplete the tissues of vitamin $B_{12}$ and appetite did not fail. The daily ration $(800 \mathrm{~g}$ wheaten hay-chaff and $50 \mathrm{~g}$ gluten) maintained the animals at constant weight throughout the experiment, no. II 3 at $42 \pm \mathrm{Ig}$ and no. 077 at $3^{8 \pm} \mathrm{I} \mathrm{kg}$.

Table 4. Respiratory exchange and energy expenditure of a vitamin $B_{12}$-deficient ewe and a pair-fed ewe treated with $50 \mu g$ vitamin $B_{12} / d$

\begin{tabular}{|c|c|c|c|c|c|c|c|c|}
\hline \multirow[b]{2}{*}{ Treatment } & \multicolumn{4}{|c|}{ Ewe 433, deficient } & \multicolumn{4}{|c|}{ Ewe 218 , treated } \\
\hline & $\begin{array}{c}\text { Oxygen } \\
\text { deficit } \\
(1 / d)\end{array}$ & $\begin{array}{c}\text { Carbon } \\
\text { dioxide } \\
\text { increase } \\
(1 / \mathrm{d})\end{array}$ & $\begin{array}{c}\text { Methane } \\
\text { evolved } \\
(1 / d)\end{array}$ & $\begin{array}{l}\text { Energy } \\
\text { dissipated } \\
\text { as heat } \\
(\mathrm{kcal} / \\
\left.\mathrm{W}^{0.73} \mathrm{~d}\right)\end{array}$ & $\begin{array}{c}\text { Oxygen } \\
\text { deficit } \\
(1 / d)\end{array}$ & $\begin{array}{c}\text { Carbon } \\
\text { dioxide } \\
\text { increase } \\
(1 / d)\end{array}$ & $\begin{array}{c}\text { Methane } \\
\text { evolved } \\
\text { (1/d) }\end{array}$ & $\begin{array}{l}\text { Energy } \\
\text { dissipated } \\
\text { as heat } \\
(\mathrm{kcal} / \\
\left.\mathrm{W}^{\mathbf{0} \cdot \mathbf{7 3}} \mathrm{d}\right)\end{array}$ \\
\hline Fed (350 $\mathrm{g}$ fodder) & 200 & 179 & 9.4 & $86 \cdot 9$ & 187 & 169 & $10 \cdot 6$ & $84 \cdot I$ \\
\hline Fasted: day I & 170 & 127 & $4 \cdot 2$ & $72 \cdot 7$ & 138 & 109 & $3 \cdot I$ & $61 \cdot 2$ \\
\hline day 2 & 162 & I I 4 & 0.7 & $72 \cdot 3$ & I 5 I & 108 & $2 \cdot 3$ & $66 \cdot 3$ \\
\hline day 3 & 157 & 98 & $I \cdot I$ & $69 \cdot 1$ & 142 & 94 & $1 \cdot 2$ & $62 \cdot 3$ \\
\hline
\end{tabular}

Table 5. Energy expenditure on the $\mathrm{x}$ st day of fast of a vitamin $B_{12}$-deficient ewe and a pair-fed ewe treated with $50 \mu \mathrm{g}$ vitamin $B_{12} / d$

\begin{tabular}{|c|c|c|c|c|}
\hline \multirow[b]{2}{*}{$\begin{array}{l}\text { Time after } \\
\text { pairing } \\
\text { (weeks) }\end{array}$} & \multicolumn{2}{|c|}{ Ewe 072 , deficient } & \multicolumn{2}{|c|}{ Ewe I4I, treated } \\
\hline & $\begin{array}{c}\text { Body-weight } \\
(\mathrm{kg})\end{array}$ & $\begin{array}{c}\text { Energy } \\
\text { dissipation } \\
\left(\mathrm{kcal} / \mathrm{W}^{0 \cdot 73} \mathrm{~d}\right)\end{array}$ & $\begin{array}{c}\text { Body-weight } \\
\text { (kg) }\end{array}$ & $\begin{array}{c}\text { Energy } \\
\text { dissipation } \\
\left(\mathrm{kcal} / \mathrm{W}^{0.73} \mathrm{~d}\right)\end{array}$ \\
\hline 12 & $20 \cdot 3$ & $66 \cdot 9$ & $2 I \cdot 0$ & 59.4 \\
\hline 14 & $20 \cdot 0$ & $67 \cdot 6$ & $20 \cdot 4$ & $58 \cdot 6$ \\
\hline
\end{tabular}

After 4 weeks stabilization of both animals, with no. I 13 receiving $\mathrm{Co}$, the energy and nitrogen available from the ration were determined from collection of excreta over I $4 \mathrm{~d}$. During the subsequent I $4 \mathrm{~d}$, eight $24 \mathrm{~h}$ measurements of respiratory exchange were made on each animal. Treatment was then reversed and after $\mathrm{I}_{4} \mathrm{~d}$ stabilization the above procedure was repeated except that ten instead of eight measurements of respiratory exchange were made. During the $\mathrm{i} 4 \mathrm{~d}$ periods in which excreta were collected, daily determinations of faecal dry weight were made and these, together with the replicate measurements of respiratory exchange, were used in statistical analysis of the results. That $\mathrm{I}_{4} \mathrm{~d}$ without Co is more than sufficient to deplete the rumen of Co and vitamin $B_{12}$ was shown by Smith \& Marston (1970), and the rapidity of the response in food intake and body-weight of deficient animals to Co given orally (Marston \& Smith, 1952; Marston, 1970) indicates that the reverse is also true.

The results for energy and nitrogen retention from the diet are shown in Table 6, and for energy expenditure in Table 7 . The statistical analysis showed that there was no significant effect of orally administered Co on any of the quantities measured. 
Table 6. Effect of I mg cobalt/d given by mouth on nitrogen and energy retention by sheep eating the Co-deficient ration but not yet deficient of vitamin $B_{12}$

\begin{tabular}{|c|c|c|c|c|c|c|}
\hline & \multicolumn{6}{|c|}{ Ewe 077} \\
\hline & \multicolumn{3}{|c|}{ Period $\mathrm{A}$, untreated } & \multicolumn{3}{|c|}{ Period B, treated } \\
\hline & $\mathrm{g}(\mathrm{dry}) / \mathrm{d}$ & $\underset{(g / d)}{N}$ & $\begin{array}{c}\text { Combustible } \\
\text { energy } \\
\text { (kcal/d) }\end{array}$ & $\mathrm{g}(\mathrm{dry}) / \mathrm{d}$ & $\underset{(g / d)}{N}$ & $\begin{array}{c}\text { Combustible } \\
\text { energy } \\
\text { (kcal/d) }\end{array}$ \\
\hline Ration: chaff & 690 & $8 \cdot 53$ & 2920 & 677 & $8 \cdot 62$ & 2930 \\
\hline gluten & $45 \cdot 5$ & 6.08 & 255 & $45 \cdot 5$ & 6.08 & 255 \\
\hline Food residues & o & 0 & 0 & 0 & o & 0 \\
\hline $\begin{array}{c}\text { Net intake: } \\
\text { faeces } \\
\text { urine }\end{array}$ & $\begin{array}{c}735 \cdot 5 \\
319 \pm 7.0 \\
\end{array}$ & $\begin{array}{c}14.61 \\
4.34 \pm 0.10 \\
8.18\end{array}$ & $\begin{array}{c}3175 \\
\mathrm{I} 404 \pm 31 \cdot 0 \\
\times 30\end{array}$ & $\begin{array}{c}722 \cdot 5 \\
323 \pm 7 \cdot 0 \\
-\end{array}$ & $\begin{array}{c}14.70 \\
4.62 \pm 0.10 \\
8.10\end{array}$ & $\begin{array}{c}3185 \\
1415 \pm 30 \cdot 8 \\
126\end{array}$ \\
\hline Output in: & & & & & & \\
\hline visible excreta & - & $12 \cdot 52 \pm 0.10$ & I $534 \pm 31 \cdot 0$ & - & $12 \cdot 72 \pm 0.10$ & I $541 \pm 30 \cdot 8$ \\
\hline methane & 一 & - & $176 \pm 3.4$ & - & - & $199 \pm 2 \cdot 2$ \\
\hline Total output & 一 & $12.52 \pm 0.10$ & $1710 \pm 31 \cdot 1$ & 一 & $12.72 \pm 0.10$ & $1740 \pm 30.9$ \\
\hline Retained & 一 & $2.09 \pm 0.10$ & $1465 \pm 3 I \cdot I$ & - & $1 \cdot 98 \pm 0.10$ & $1445 \pm 30 \cdot 9$ \\
\hline
\end{tabular}

\begin{tabular}{|c|c|c|c|c|c|c|}
\hline \multirow{4}{*}{$\begin{array}{r}\text { Ration: chaff } \\
\text { gluten }\end{array}$} & \multicolumn{6}{|c|}{ Ewe I 13} \\
\hline & \multicolumn{3}{|c|}{ Period A, treated } & \multicolumn{3}{|c|}{ Period B, untreated } \\
\hline & 690 & $8 \cdot 53$ & 2920 & 677 & 8.62 & 2930 \\
\hline & $45 \cdot 5$ & 6.08 & 255 & $45 \cdot 5$ & $6 \cdot 08$ & 255 \\
\hline Food residues & 0 & $\circ$ & 0 & 0 & $\circ$ & 0 \\
\hline Net intake: & 735.5 & $14.6 \mathrm{I}$ & 3175 & $722 \cdot 5$ & 1470 & 3185 \\
\hline faeces & 3 I I $\pm 7 \cdot 0$ & $4.04 \pm 0.09$ & I $359 \pm 30 \cdot 8$ & $299 \pm 7 \cdot 0$ & $4.07 \pm 0.10$ & I $319 \pm 3 I \cdot I$ \\
\hline $\begin{array}{r}\text { urine } \\
\text { Output in: }\end{array}$ & & & 128 & - & $8 \cdot 68$ & I 32 \\
\hline visible excreta & 一 & I $2.59 \pm 0.09$ & $1487 \pm 30 \cdot 8$ & 一 & I $2.75 \pm 0.10$ & I $45 \mathrm{I} \pm 3 \mathrm{I} \cdot \mathrm{I}$ \\
\hline $\begin{array}{l}\text { methane } \\
\text { Total output }\end{array}$ & - & - & $206 \pm 15 \cdot x$ & 一 & - & $226 \pm 5 \cdot 8$ \\
\hline Total output & 一 & $12.59 \pm 0.09$ & I $693 \pm 34.3$ & - & $12.75 \pm 0.10$ & $1677 \pm 31 \cdot 6$ \\
\hline Retained & - & $2.02 \pm 0.09$ & $1482 \pm 34 \cdot 3$ & - & $1.95 \pm 0.10$ & $1508 \pm 31 \cdot 6$ \\
\hline
\end{tabular}

\section{DISCUSSION}

It was clear from previous work (Marston, 1970) that either Co given orally or injected vitamin $B_{12}$ was capable of preventing the loss of appetite and bodyweight suffered by sheep given a Co-deficient diet. The capacity of deficient animals to respond immediately to short periods of treatment with vitamin $B_{1.2}$ is shown in Fig. $I$ to be sustained for periods approaching 4 years, and since only small amounts of injected vitamin $B_{12}$ enter the rumen (Smith \& Marston, 1970) it may be concluded that the deficiency symptoms are predominantly due to lack of vitamin $B_{12}$ in the tissues. That they may be ascribed entirely to this cause is suggested by the values in Tables 6 and 7 where the presence of additional Co (and hence of cobamides) in the rumen had, within small limits of error, no effect either on the digestibility of the fodder or on the energy or nitrogen metabolism of the animal.

These findings do not support the suggestion (Ford, Kon \& Porter, 1952; Porter, 1953) that relatively high concentrations of cobamides may be necessary for normal 


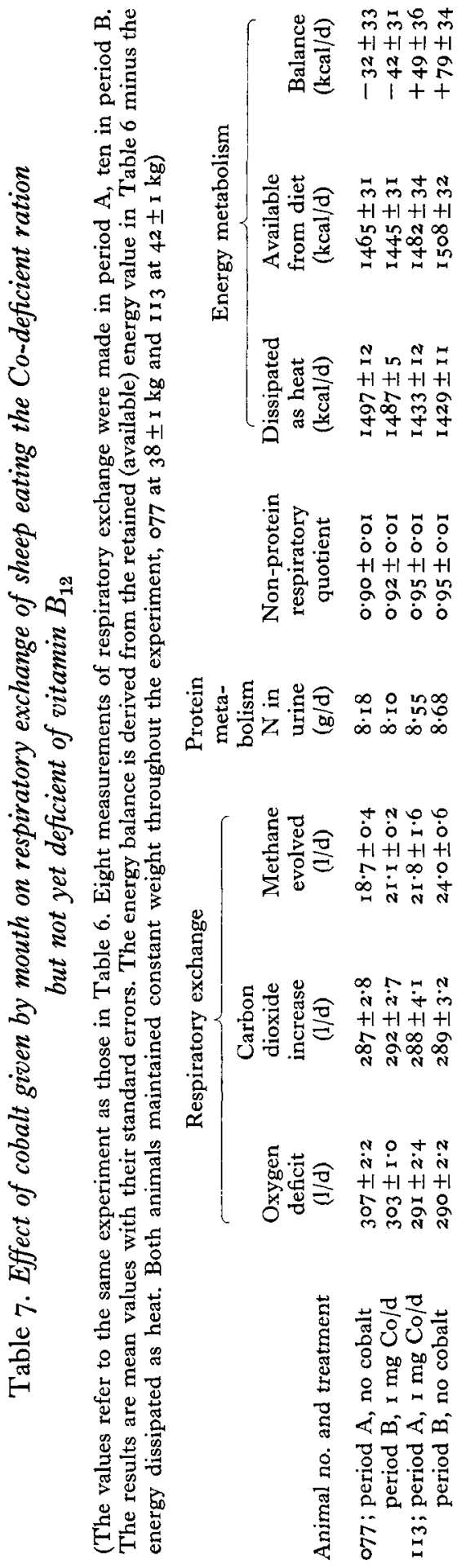


ruminal fermentation. It is not improbable that some microbial functions in the rumen do necessitate vitamin $B_{12}$ or other cobamides, but the minimum requirements for effective fermentation can evidently be met at a level of dietary Co too low to support the requirements of the animal's tissues for vitamin $B_{12}$. Synthesis of methane in the rumen, for example, probably depends, at least in part, on the participation of cobamides (Stadtman \& Blaylock, I966; Blaylock, I968), but in the present work the absence of supplementary Co had no effect on methane production (Table 7 ), and in the vitamin $B_{12}$-deficient animal methane production was reduced only in proportion to food intake (Table 4 compared with Table 7). The reduction in bacterial counts in the Co-depleted rumen (Gall, Smith, Becker, Stark \& Loosli, I949), if it occurred in the present experiments, did not appear to affect the availability of energy or nitrogen from the diet.

The relative rates of body-weight loss of pair-fed deficient and vitamin $B_{12}$-treated animals (Table I) clearly establish the more rapid loss of weight by the former. The wide variation in individual ratios between pairs was also found in repeat measurements of single pairs and probably reflects the imprecision of body-weights in ruminants. That the difference between deficient and treated animals represents a loss of tissue substance and not of water is indicated by the similarity of muscle composition in deficient animals and Co-treated animals on restricted food intake (Holmes, 1965). From Fig. $\mathrm{I}$ it is clear that these losses are made good when the deficient animal is treated with vitamin $B_{12}$. The extent of the metabolic inefficiency in deficient animals implied by these findings appears to be characteristic of the deficiency state and to be maintained through successive cycles of deficiency.

With a variable and falling daily food intake, conditions for measurement of energy and nitrogen metabolism in pair-fed animals were not ideal, and only tentative conclusions can be reached from the limited number of observations made. The finding of a higher faecal nitrogen excretion together with a higher fasting energy expenditure in deficient than in pair-fed treated animals, however, is consistent with the higher rate of body-weight loss in the former.

The major cause of body-weight loss in the vitamin $\mathrm{B}_{12}$-deficient sheep was loss of appetite, but a substantial metabolic inefficiency existed as well. The extent of the metabolic inefficiency showed no correlation with the rate of loss of appetite (as reflected in body-weight losses) and there is therefore no evidence to suggest that these two manifestations of vitamin $B_{12}$ deficiency were causally related.

Thanks are due to Dr E. A. Cornish and Mr W. B. Hall, CSIRO Division of Mathematical Statistics, for analysis of results. Acknowledgement is also made to Dr G. B. Jones and the Analytical Section of this Division for some of the analytical work, to Mr C. E. Sleigh for operation of the calorimeters and to Mr R. Burns for care of the animals. 


\section{REFERENCES}

Blaylock, B. A. (1968). Archs Biochem. Biophys. 124, 314.

Ford, J. E., Kon, S. K. \& Porter, J. W. G. (1952). Chemy Ind. 22, 495.

Gall, L. S., Smith, S. E., Becker, D. E., Stark, C. N. \& Loosli, J. K. (r949). Science, N. Y. rog, 468. Holmes, E. G. (I965). Q. Fl exp. Physiol. 50, 203.

Marston, H. R. (1935). F. agric. Sci., Camb, 25, 103.

Marston, H. R. (1948). Aust. F. scient. Res. B, I, 93 .

Marston, H. R. (1952). Physiol. Rev. 32, 66.

Marston, H. R. (1970). Br. F. Nutr. 24,615.

Marston, H. R. \& Dewey, D. W. (1940). Aust. F. exp. Biol. med. Sci. 18, 343.

Marston, H. R. \& Lee, H. J. (I 948). F. agric. Sci., Camb. 38, 229.

Marston, H. R. \& Smith, R. M. (I952). Nature, Lond. 170, 792.

Porter, J. W. G. (1953). Proc. Nutr. Soc. 12, 106.

Smith, R. M. \& Marston, H. R. (1970). Br. F. Nutr. 24, 857.

Stadtman, T. C. \& Blaylock, B. A. (1966). Fedn Proc. Fedn Am. Socs exp. Biol. 25 , I657.

Underwood, E. J. (1962). Trace Elements in Human and Animal Nutrition 2nd ed., p. 134. London: Academic Press. 